\title{
IDEOLOGI DAN TEKNIK PENERJEMAHAN FRASA PADA BUKU BIOGRAFI SUHARTO (A POLITICAL BIOGRAPHY) DARI BAHASA INGGRIS KE DALAM BAHASA INDONESIA KARYA R.E. ELSON \\ (STUDI ANALISI ISI)
}

\author{
Pebri Prandika Putra, M.Hum. \\ IAIN Bengkulu \\ Bengkulu, Indonesia \\ pebri_dika89@yahoo.com
}

\begin{abstract}
Ideology in the translation process is important in deciding towards what kind of direction the translation will go. If the primary purpose of the translation is to promote the culture and techniques, it is considered adequate to choose the foreignization over the domestication as the ideology of the translation when it comes to the translation of culture-specific items. It also discussed those techniques used in the object of the research. The object of the research was A Political Biography of Suharto. This research was content analysis where focus on the object and the researcher as instrument. The result of this reserach found out that the most ideology used was domestiction and the technique was pure borrowing. There was significant relationship between domestication ideology and pure borrowing. It was meant The technique oriented to source language
\end{abstract}

Key words: Translation, Ideology, Translation techniques

Abstrak: Ideolgy dalam proses penerjemahan sangat penting dalam menentukan kemana arah terjemahan dituju. Jika tujuan utama penerjemahan adalah untuk mengenalkan ideology dan teknik maka perlu mempertimbangkan idelogy lokal atau asing yang harus digunakan dalam pengembangan budaya bahasa. Penelitian ini juga mendiskusikan teknik yang digunakan dalam proses penerjemahan objek. Objek penelitian ini adalah buku biografi politik Suharto. Metode penelitian yang digunakan adalah analisis isi dan peneliti sebagai instrumennya. Hasil dari penelitian ini ditemukan bahwa ideologi yang paling banyak digunakan adalah lokal dan tekniknya adalah peminjaman alami. Terdapat hubungan erat antara ideologi lokal dan teknik tersebut yang artinya penerjemah telah berorientasi pada bahasa sumber (bsu)

Kata Kunci : Penerjemahan, Ideologi, Teknik Penerjemahan 


\section{Pendahuluan}

Di era informasi saat ini, tidaklah berlebihan bila dikatakan bahwa penerjemahan menjadi bagian yang penting dalam kehidupan masyarakat Indonesia. Berkat terjemahan, masyarakat Indonesia dapat menggali berbagai macam informasi dari negara lain tanpa harus belajar bahasanya terlebih dahulu. Terjemahan dapat juga membuka pintu informasi di seluruh dunia, menghilangkan dinding pemisah antar bangsa, sarana kerjasama, pemahaman budaya, dan perdamaian dunia.Selain itu, penerjemahan juga dapat digunakan sebagai sarana pembelajaran suatu bahasa. Dengan demikian, tanpa adanya penerjemahan maka akan terjadi hambatan bahasa (language barrier) di tengah-tengah masyarakat.

Dari pemikiran di atas upaya penerjemahan buku-buku berbahasa asing ke dalam bahasa Indonesia terus dilakukan oleh pemerintah, institusi swasta, penerbit, dan kelompok atau pribadi yang mempunyai perhatian dalam bidang penerjemahan. Hal ini disebabkan juga karena negara Indonesia adalah negara berkembang yang masihmengadaptasi ilmu pengetahuan dan teknologi yang berasal dari negara lain. Sehingga dapat dikatakan bahwa penerjemahan adalah jembatan ilmu bagi peradaban manusia.

Fenomena di atas harus pula diimbangi dengan kualitas terjemahan.Setiap orang memang berhak melakukan kegiatan penerjemahan selama memiliki kapasitas dalam hal tersebut, tetapi perlu dipertimbangkan pula sisi kualitas terjemahan yang dihasilkan.Kualitas terjemahan yang rendah bisa saja ditarik dari pasaran karena dianggap tidak layak dipublikasikan di tengah masyarakat pembaca buku terjemahan.

Kualitas terjemahan yang baik membutuhkan proses yang tidak sederhana karena pengetahuan bahasa, pragmatis dan budaya kedua bahasa yang berbeda haruslah dikuasi. Hal tersebut berdasarkan pendapat Larson yang mengatakan bahwa penerjemahan mengkaji leksikon, struktur gramatikal, situasi komunikasi, dan konteks budaya serta ideology dalam teks sumber lalu menganalisis untuk menentukan maknanya dan kemudian menyusun kembali makna yangsama dengan menggunakan leksikon dan struktur gramatikal yang tepat dalam bahasa dan konteks budaya sasaran. ${ }^{1}$

Penerjemahan pada wilayah ideologi telah masuk pada ranah nilai dan norma serta keyakinan yang melandasi seorang penerjemah memutuskan apa yang harus dilakukan dengan teks terjemahannya.Ketika berhadapan dengan teks-teks yang mengandung nilai-nilai atau paham tertentu penerjemah lagi-lagi menjadi pihak yang tidak bisa sepenuhnya netral dalam mempertahankan keakuratan.Terjemahan akan selalu diwarnai pengetahuan, keyakinan serta nilai atau bahkan terjemahan akan mengalami mediasi, distorsi dan interferensi.

Politik dan budaya adalah dua aspek yang dapat diselami malalui 
ideologi penerjemahan. Penelti merasa perlu melihat gaya pemikiran dan ideologi penerjemahan yang digunakan penerjemah dalam menerjemahkan aspek politik dan budaya yang terdapat dalam biografi politik Suharto dengan jumlah halaman sebanyak 604 halaman dan uniknya biografi tersebut ditulis oleh sejarawan dari Australia bernama R.E Elson.

Terdapat dua ideologi yang menjadidua kutub berlawanan yang membentukpandangan mengenai cara \&strategi yang diambilnya dalam penerjemahanpada tataran global hingga ketataran mikro. Penerjemah yang memilikiorientasi ke bahasa sumber(foreignization) cenderung mempertahankanbentuk asli terjemahansehingga produknya terasa sebagaikarya terjemahan. Sementara penerjemahanyang memiliki orientasi kebahasa sasaran (domestication) cenderungberupaya agar hasil terjemahanterasa sebagai teks asli dalam Bsa.

Pada prakteknya, kedua ideology tersebut muncul dalam masyarakat.Disadari atau tidak, cara kita saatmengemukakan ulang ide, gagasan,terikat dengan ideologi (keyakinan) kitapada konsep yang lebih luas. Secaralinguistik hal ini tercermin dari penggunaanbahasa saat mengemukakan idetersebut yang menampilkan sikap,keyakinan, dan nilai yang dimiliki olehsuatu kelompok tertentu atau masyarakat.2dapat Penerjemahdengan ideologi foreignisasi cenderungmempertahankan gaya penulis asli,sehingga ia lebih cenderung menggunakanmetode atau teknik penerjemahan yang menekankanpada Tsu.Berikut contoh terbentuknya idologi foreignisasi.

\begin{tabular}{|c|c|c|}
\hline $\begin{array}{l}\text { Bahasa } \\
\text { Sumber } \\
(\mathrm{BSu})\end{array}$ & $\begin{array}{c}\text { Bahasa } \\
\text { Sasaran } \\
(\text { Bsa })\end{array}$ & Ideologi \\
\hline $\begin{array}{l}\text { In the } \\
\text { surrounds } \\
\text { of } \\
\text { Magelang } \\
\text { Republica } \\
\mathrm{n} \text { troops } \\
\text { are still } \\
\text { carrying } \\
\text { out } \\
\text { clearing } \\
\text { operations } \\
\text { agaist } \\
\text { rebels. }\end{array}$ & \begin{tabular}{l}
\multicolumn{1}{c}{ Di } \\
sekitar \\
Magelang, \\
pasukan \\
Republik \\
masih \\
melancarka \\
n operasi \\
pembersiha \\
n terhadap \\
pemberonta \\
kan
\end{tabular} & $\begin{array}{l}\text { foreignis } \\
\text { asi }\end{array}$ \\
\hline
\end{tabular}

Pada data di atas terlihat penerjemah mencoba mengikuti pola grammatical bahasa sumber. Sebuah frasa preposisi lokatif in the surrounds of Magelang yang diterjemahkan mengggunakan teknik harfiah menjadi 'di sekitar Magelang'. Terjemahan tersebut mengindikasi bahwa penerjemah telah menggunakan ideologi foregnisasi pada penggalan kalimat yang mengandung aspek politik tersebut. Apabila melihat keseluruhan dari kalimat jelas bahwa penerjemah menggunakan ideologi foregnisasi hal ini disebabkan teknik harfiah yang diterapkan dan penerjemah mencoba mempertahankan budaya bahasa yang ada pada bahasa sumber. 


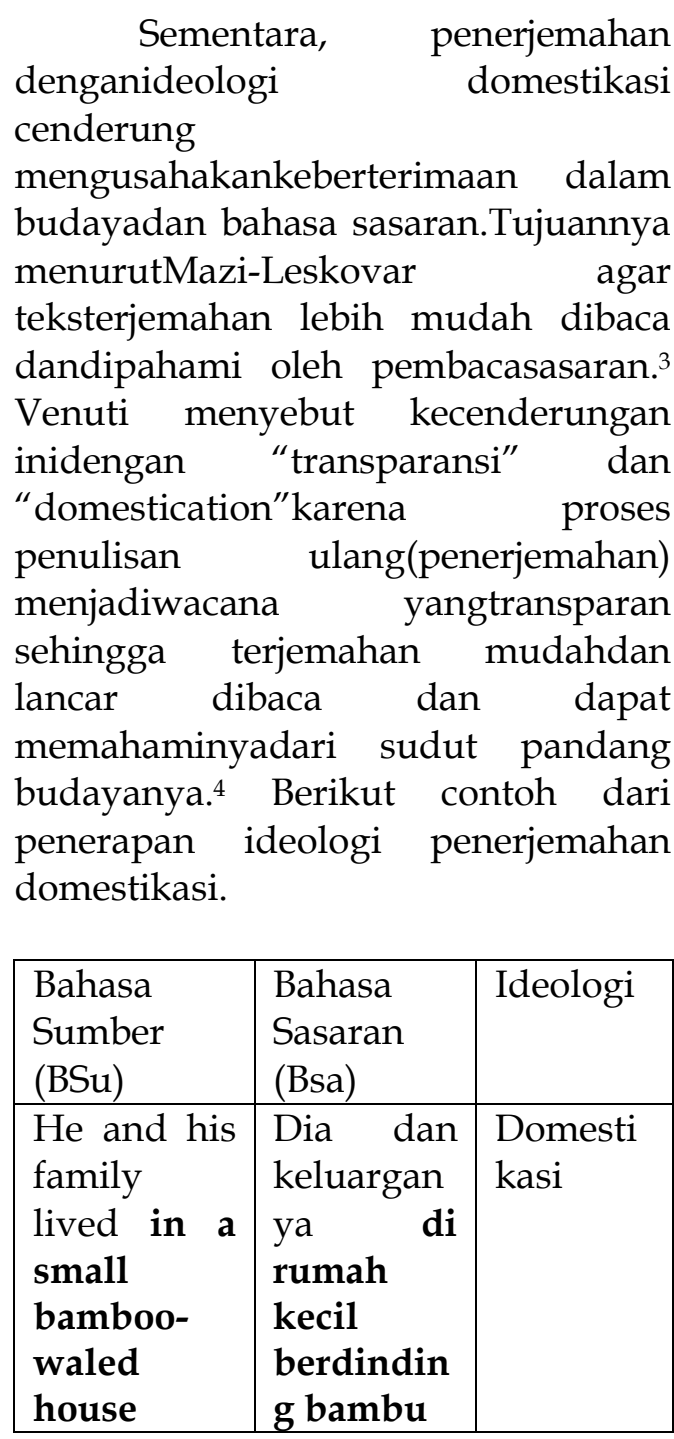

Frasa preposisi lokatif in a small bamboo-waled house yang diterjemahkan menjadi 'di rumah kecil berdinding bambu' telah mengalami pergeseran struktur (Structure Shift). Dalam pola bahasa sumber kata small merupakan adjektiva atau modifier yang menerangkan nomina house telah berubah pola ketika di dalam bahasa sasaran yaitu bahasa indonesia menjadi diterangkan-menerangkan sehingga frasanya berubah menjadi 'rumah kecil'. Pengubahan pola dengan menyesuaikan pada bahasa sasaran merupakan bagian dari penerapan ideologi domestikasi dimana penerjemah mencoba mempertahankan budaya bahasa sasaran dan tingkat keterbacaan yang baik.

Peneliti juga akan mengkaji secara mendalam penyimpangan penerjemahan ideologi yang terdapat pada biografi Suharto (A Political Biography) secara mendalam serta melihat potensi penggunaan teknik penerjemahan yang diterapkan penerjemah biografi tersebut. Oleh karena itu peneliti akan melakukan penelitian analisis isi dengan judul "Ideologi dan Teknik Penerjemahan Frasa Pada Buku Biografi Suharto (A Political Biography) Dari Bahasa Inggris Ke Dalam Bahasa Indonesia Karya R.E. Elson."

\section{Pembahasan}

\section{A. Ideology Penerjemahan}

Sebelum menerjemahkan, seorang penerjemah harus mengetahui untuk siapa (audience design) dan untuk tujuan apa (needs analysis) dia menerjemahkan. Proses ini merupakan salah satu proses yang tidak dapat diabaikan dalam menerjemahkan karena merupakan proses awal dalam menetukanmetode penerjemahan yang akan dan harus digunakan. Setelah mengetahui audience design dan needs analysis seorang penerjemah harus 
mengetahui langkah-langkah penerjemahan yang biasa disebut sebagai prosedur penerjemahan ${ }^{5}$.

Penerjemahan merupakan reproduksi pesan yang tekandung dalam TSu.Hoed mengutip pernyataan Basnett dan Lefevere bahwa apapun tujuannya, setiapreproduksi selalu dibayangi oleh ideologi tertentu. ${ }^{6}$ Ideologi dalam penerjemahan adalah prinsip atau keyakinan tentang betul-salah dan baikburuk dalam penerjemahan, yakni terjemahan seperti apa yang terbaik bagi masyarakat pembaca BSa atau terjemahan seperti apa yang cocok dan disukai masyarakat tersebut.

Ideologi yang digunakan penerjemah merupakan tarik-menarik antara dua kutub yang berlawanan, antara yang berorientasi pada BSu dan yang berorientasi pada BSa (Venuti dalam Hoed), ${ }^{7}$ yang oleh Venuti dikemukakan dengan istilah foreingnizing translation dan domesticating translation. Berikut adalah uraian mengenai kedua hal tersebut dengan berlandaskan pada paparan Hoed ${ }^{8}$.

\section{A.1 Foreignizing Ideology (Ideology Foregnisasi/Asing)}

Foreignizing translation adalah
ideologi penerjemahan yang berorientasi pada $\mathrm{BSu}$, yakni bahwa penerjemahan yang betul, berterima, dan baik adalah yang sesuai dengan selera dan harapan pembaca, penerbit, yang menginginkan kehadiran kebudayaan BSu atau yang menganggap kehadiran kebudayaan asing bermanfaat bagi masyarakat.Penerjemah sepenuhnya berada di bawah kendali penulis TSu.Di sini yang menonjol adalah suatu aspek kebudayaan asing yang diungkapkan dalam bahasa pembaca.Sekait dengan Diagram-V dari Newmark, metode yang dipilih biasanya juga metode yang berorientasi pada Bsu, yaitu cenderung menggunakan jenis penerjemahan setia dan penerjemahan semantik.

Sekait dengan ideologi ini, sebagai ilustrasi eorang penerjemah tidak menerjemahkan kata-kata $M r$, Mrs, Mom, Dad dan sejumlah kata asing lainnya dalam penerjemahan dari bahasa Inggris dengan alasan sapaan seperti itu tidak lagi asing bagi pembaca Indonesia, hal ini merupakan ciri bahwa penerjemah tersebut penganut ideologi Foreignizing Translation. Alasan lain yang dapat dikemukakan adalah agar anak-anak memperoleh pengetahuan kebudayaan lain.

\section{A.2 DomesticationIdeology (Ideology Domestikasi/Lokal)}

Domesticating translation adalah ideologi penerjemahan yang berorientasi pada BSa. Ideologi ini meyakini bahwa penerjemahan yang betul, berterima, dan baik adalahyang sesuai dengan selera dan harapan pembaca yang menginginkan teks terjemahan yang sesuai dengan kebudayaan masyarakat BSa. Intinya, suatu terjemahan diharapkan tidak terasa seperti terjemahan. Terjemahan harus menjadi bagian dari tradisi tulisan dalam BSa. Oleh karena itu, penerjemah menentukan apa yang diperlukan agar terjemahannya tidak dirasakan sebagai karya asing bagi 
pembacanya. Sekait dengan DiagramV dari Newmark, biasanya metode yang dipilih pun adalah metode yang berorientasi pada BSa seperti adaptasi, penerjemahan idiomatik, dan penerjemahan komunikatif.

Bagi penganut ideologi domesticating, kata-kata asing seperti Mr, Mrs, Uncle, Aunt dan sebagainya harus diterjemahkan ke dalam bahasa Indonesia agar keseluruhan terjemahan hadir sebagai bagian dari bahasa Indonesia sehingga berterima di kalangan pembaca BSa. Ia akan berusaha memperkenalkan kebudayaan Indonesia pada dunia luar karena baginya penerjemahan yang betul adalah yang berterima dalam BSa dan tidak menghadirkan sesuatu yang asing.

Kecenderungan ini sudah dikemukakan pula oleh pakar teori penerjemahan, Nida dan Taber dalam Hoed yang secara tegas mengemukakan bahwa penerjemahan yang baik berorientasi pada keberterimaan dalam bahasa pembacanya. ${ }^{9}$ Kedua pakar ini dipandang sebagai pendukung ideologi yang berorientasi pada kebudayaan BSa atau domestication.

\section{B. Frasa}

\section{B.1 Pengertian Frasa}

Frasa adalah kesatuan yang terdiri atas dua kata atau lebih, yang masing-masingnya mempertahankan makna dasar katanya, sementara gabungan itu menghasilkan suatu relasi tertentu, dan tiap kata pembentuknya tidak bisa berfungsi sebagai subjek dan predikat dalam konstruksi itu. Jadi, gabungan seperti :rumah ayah, nasi padang, anak pintar dan makan nasi tetap mempertahankan makna dasar kata-kata itu, sementara hubungan antara kata-kata itu menimbulkan suatu relasi tertentu. ${ }^{10}$

Contoh di atas menunjukan relasi dari dua kata yang berbeda. Antara kata rumah dan ayah timbul sebuah relasi milik yang tadinya tidak ada, antara kata nasi dan padang terdapat hubungan asal, antara kata anak dan pintar terdapat hubungan kualitas dan sebagainya. ${ }^{11}$

Di sisi lain Kridalaksana menejelaskan bahwa frasa adalah satuan gramatikal yang berupa gabungan kata yang bersifat non predikatif. ${ }^{2}$ Pendapat tersebut dipertegas oleh Finoza yang mengatakan bahwa frasa adalah sekelompok kata yang tidak mengandung predikat dan belum membentuk klausa atau kalimat. Frasa tidak boleh mengandung predikat karena kelompok kata yang mengandung predikat akan membentuk klausa, bahkan dapat membentuk kalimat. Yang dimaksud predikat adalah kata atau kelompok kata yang menyatakan perbuatan/tindakan, keadaan atau sifat dari subjek. ${ }^{13}$ Thronbury juga berpendapat bahwa frasa terjadi pada tataran gramatikal yang dibentuk dari dua kata atau lebih. ${ }^{14}$

Berdasarkan pendapat para ahli di atas dapat disimpulkan bahwa frasa merupakan bagian yang tidak dapat dipisahkan dalam pembentukan sebuah klausa atau kalimat, karena pada dasarnya setiap unsur tersebut saling berkaitan satu sama lain. Di dalam hal pembentukan frasa preposisi lokatif, peran frasa sangatlah 
penting untuk menunjukan identitas dari frasa preposisi lokatif tersebut.

\section{B.2 Jenis-Jenis Frasa}

Pada dasarnya tidak ada perbedaan yang mendasar antara frasa dalam bahasa Indonesia dan frasa dalam bahasa Inggris. Menurut Kridalaksana frasa dalam bahasa Indonesia terbagi menjadi dua yaitu frasa eksosentris dan frasa endosentris. Frasa eksosentris adalah frasa yang sebagian atau seluruhnya tidak mempunyai perilaku sintaksis yang sama dengan komponenkomponennya.

Frasa eksosentris mempunyai dua komponen; yang pertama yang disebut perangkai berupa preposisi atau partikel seperti si, para, kaum, yang.Komponen kedua yang disebut sumbu berupa kata atau kelompok kata. Frasa endosentris adalah frasa yang keseluruhannya mempunyai perilaku sintaksis yang sama dengan salah satu bagiannya. Ada frasa endosentris berinduk satu atau frasa modifikasi dan frasa endosentis berinduk banyak. ${ }^{15}$

Widjono memilliki penjelasan yang sama bahwa frasa dapat dibedakan berdasarkan kelas katanya, yaitu frasa verbal, frasa adjektival, frasa nominal, frasa pronominal, frasa adverbial, frasa numerial, frasa koordinativa koordinatif, frasa demonstrativa koordinatif dan frasa preposisional koordinatif. ${ }^{16}$

Di dalam bahasa Inggris pun memiliki jenis frasa yang hampir sama dengan bahasa Indonesia yaitu noun phrase, verb phrase, adjective phrase, adverb phrase dan preposisitional phrase.Noun phrase (frasa nomina) adalah frasa yang dapat berfungsi sebagai subyek atau obyek dalam sebuah kalimat.Verb phrase (frasa kata kerja) adalah frasa yang terdiri dari gabungan kata kerja (auxiliary verb) dengan kata kerja (verb) yang membentuk suatu bentuk waktu (tense) tertentu.

Adjective phrase (frasa kata sifat) adalah frasa yang memiliki fungsi seperti kata sifat yang digunakan untuk menerangkan kata benda.Adverb phrase (frasa kata keterangan) adalah frasa yang berfungsi sebagai kata keterangan.preposisitional phrase (frasa preposisi) adalah pengabungan antara preposisi dan frasa nomina yang saling meiliki relasi satu sama lain. ${ }^{17}$

Dari penjelasan di atas dapat disimpulkan bahwa jenis-jenis frasa merupakan indikasi terbentuknya suatu tataran yang lebih tinggri seperti klausa atau kalimat. Dengan melihat jenis-jenis frasa maka kita akan lebih paham ketika menjawab jenis frasa apa yang sedang ditanyakan kepada kita.

Penelitian ini bermaksud menginventarisir teknik yang digunakan pada hasil terjemahannya. Teknik penerjemahan merupakan perwujudan strategi yang dipilih oleh penerjemah. Pemilihan teknik ini tentunya tergantung pada konteks, tujuan dan jenis penerjemahan, serta perkiraan target pembaca. Tujuan pemilihan teknik tersebut sesuai dengan tujuan penerjemahan, yaitu agar pembaca dapat memperoleh pesan yang disampaikan, namun apapun pilihan teknik tersebut tentu 
memiliki risiko atau dampak pada hasil terjemahan.

Menurut Molina dalam

Translators' Journal, ada 15 macam teknik penerjemahan, berikut penjelasannya;

a. Peminjaman (borrowing), adalah teknik mengambil sebuah kata atau istilah langsung dari bahasa sumber. Peminjaman langsung ini disebut peminjaman murni (pure borrowing), sedangkan peminjaman yang menggunakan penyesuaian fonetik dan morfologi bahasa sasaran adalah teknik peminjaman alamiah (naturalized borrowing). Contohnya; kata harddiskyang diterjemahkan harddisk disebut peminjaman murni (pure borrowing), kata computer yang diterjemahkan komputer disebut peminjaman alami (naturalized borrowing).

b. Kalke (calque), adalah teknik yang menerjemahkan kata asing atau frasa ke dalam bahasa sasaran dengan menyesuaikan struktur bahasa sasaran. Contohnya: beautiful girl diterjemahkan menjadi gadis cantik.

c. Penerjemahan Harfiah (literal translation), adalah penerjemahan kata-demikata. Yang dimaksud dengan kata demi kata ini bukan berarti menerjemahkan satu kata untuk kata yang lainnya, tetapi lebih cenderung kepada menerjemahkan kata demi kata berdasarkan fungsi dan maknya dalam tataran kalimat. Contohnya I go to school diterjemahkan aku pergi ke sekolah.

d. Transposisi (transposition), adalah teknik yang mengganti kategori gramatika. Teknik transposisi sama dengan teknik pergeseran unit, struktur dan kategori. Contohnya: neuorologis disorders menjadi kelainan neurologis.

e. Modulasi (modulation), adalah teknik penerjemahan yang mengalami perubahan sudut pandang, fokus atau kategori kognitif yang ada pada teks sumber baik secara leksikal maupun struktural. Contohnya: I Kick the ball diterjemahkan menjadi Bola ku tendang.

f. Adaptasi (adaptation), adalah teknik penerjemahan yang menggantikan elemen bahasa sumber dengan elemen yang diterima dan dikenal dalam bahasa sasaran. Contohnya: cricket menjadi kasti.

g. Amplifikasi (amplification), adalah teknik yang memberikan rincian penjelasan terhadap satu istilah dalam bahasa sasaran. Jika ditinjau dari kasusnya, amplifikasi itu hampir sama dengan Paraphrase-nya Newmark dan Addition-nya Nida. Nida menyatakan teknik penambahan 
(addition) dilakukan untuk mengklarifikasi sebuah ekspresi elipsis, menghindari kataksaan atau ambiguitas, mengubah sebuah kategori gramatikal, menjelaskan unsur implisit, menambah konektor. Contohnya;

Tsu : Employes of all industries took part in the conference

Tsa : Karyawan-karyawan dari semua cabang industri mengambl bagian dalam konferensi tersebut

Terdapat penambahan kata cabang untuk memperjelas industri.

h. Deskripsi (description), adalah teknik yang memberikan penjelasan atau gambaran bentuk dan fungsi suatu istilah dari bahasa sumber ke dalam bahasa sasaran. Menurut Moentaha penerjemahan deskripsi adalah penyampaian makna dari Tsu ke dalam Tsa dengan menggunakan kombinasi kata-kata bebas, yaitu menjelaskan satuansatuan leksikal yang mencerminkan realitas spesifik negara yang satu dengan negara lainnya, karena satuan satuan seperti itu tidak mempunyai ekuivalensi. Contohnya,

Tsu : 'cow-creamer'

Tsa : 'poci yang berbentuk sapi untuk tempat susu'

i. Reduksi (reduction), adalah teknik pengurangan atau penghilangan dengan tujuan memadatkan informasi dari bahasa sumber ke dalam bahasa sasaran. Contohnya; frasa the month of fasting diterjemahkan Ramadhan.

j. Kreasi diskursif (Discursive Creation), adalah teknik penerjemahan yang berupaya untuk menentukan atau menciptakan sebuah padanan sementara yang benar-benar di luar konteks yang tak terprediksi. Contohnya, Line of the street diterjemahkan jalur/lintasan jalan (yang ramai)

k. Kesepadanan lazim (Established Equivalent), adalah teknik penerjemahan yang berupaya menggunakan sebuah istilah atau ungkapan yang dikenal (dalam kamus atau aturan bahasa sebagimana mestinya) sebagai sebuah padanan dalam Tsa. Contohnya, They are as like as two peas diterjemahkan menjadi mereka sangat mirip.

1. Kompensasi (Compensation), adalah teknik yang digunakan untuk memperkenalkan unsur informasi atau efek stilistik Tsu terhadap Tsa karena unsur atau efek tersebut tidak dapat digantikan atau tidak ada padanannya dalam Tsa. Contoh,

Tsu : (A) "Why don't you write a good thrilling detective story?" she asked. 
(B) "Me? "exclaimed Mrs. Wieke, for the first time in her life regardless of grammar.

Tsa : (A) "Mengapa Anda tidak menulis roman detektif yang menegangkan saja?" tanyanya.

(B) "Apaan? "teriak Ny. Wieke, untuk pertama kali dalam hidupnya lupa pada tata bahasa.

m. Substitusi, adalah teknik menggantikan elemenelemen linguistik menjadi paralinguistik atau intonasi. Contohnya, bahasa isyarat dalam bahasa Arab yaitu dengan menaruh tangan di dada tanda ucapan terima kasih.

n. Generalisasi, adalah teknik untuk menggunakan istilah yang lebih umum, atau kebalikan dari partikularisasi. Contohnya mansion menjadi rumah. ${ }^{18}$

\section{Metode Penelitian}

\section{A. Jenis Penelitian}

Penelitian ini adalah suatu penelitian kualitatif dengan metode analisis isi.Analisis isi merupakan suatu analisis mendalam yang dapat menggunakan teknik kuantitatif maupun kualitatif terhadap pesanpesan menggunakan metode ilmiah dan tidak terbatas pada jenis-jenis variabel yang dapat diukur atau konteks tempat pesan-pesan diciptakan atau disajikan. ${ }^{19}$ Prosedur penelitian adalah tahap-tahap yang dilakukan dalam penelitian, yaitu sejak mengusulkan judul, pengumpulan data, menyusun kerangka teori, menentukan metode yang digunakan, penganalisisan sampai pada kesimpulan yang diambil.

Weber mengatakan analisis isiadalah metodepenelitianyang menggunakanseperangkat

proseduruntuk membuat kesimpulanyang valid dari suatu teks.20Sependapat dengan Weber, Krippendorf menyatakan bahwa analisis isi memandang data sebagai perwakilan teks, citra dan ekspresi yang dicitakan untuk dilihat, dibaca, diinterpretasikan dan dilakukan untuk mendapatkan pesannya. ${ }^{21}$ Dengan kata lain, analisis isi mengkaji isi atau nilai komunikasi yang ada dalam teks atau buku yang membuat pembaca memahami isi dalam teks atau buku sesuai dengan maksudnya. Pendapat lain mengenai analisis isi disampaikan oleh Lisa M yang menyatakan analisis isiadalah prosesintelektual yang mengkategorikandata

tekstualkualitatifke dalam kelompokentitasyang sama, atau kategorikonseptual, untuk mengidentifikasi pola yang konsisten danhubunganantar tema. ${ }^{22}$ Donald Ary menambahkan analisis isi adalah metodepenelitian yang digunakanuntukmenulisbahan yang bertujuan untuk mengidentifikasikarakteristik khusus darimaterial.Bahandianalisisdapatbuk $\mathrm{u}$ teks, surat kabar, halamanweb, pidato, program televisi, iklan, komposisi musik, atau sejumlahjenis laindokumen. ${ }^{23}$ Pendapat diatas 
menunjukan bahwa analisis isi memiliki cakupan yang cukup luas untuk dikembangkan oleh para peneliti khususnya dalam konteks bahasa.Bahasa sering dijadikan fokus utama untuk diteliti.

Secara kualitatif, analisis isi dapat melibatkan suatu jenis analisis dimana isi komunikasi (percakapan, teks, tertulis wawancara, fotografi dan sebagainya) dikategorikan dan diklasifikasikan.Penggunaan metode ini ditujukan untuk mengetahui bagaimana bentuk ideologi, teknik dan permasalahan pada saat menerjemahkan frasa bahasa Inggris.

Berdasarkan uraian penelitian para pakar di atas, peneliti melakukan penelitian ini dengan menggunakan pendekatan kualitatif dengan metode analisis isi dengan menganalisis secara komprehensif dan mendeskripsikannya berdasarkan objek dan data empiris yang terkait dengan masalah bahasa yang berhubungan dengan ideologi, teknik,metodedan penyimpangan pada penerjemahan frasa bahasa Inggris dalam biografi Suharto: $A$ Political Biography.

\section{B. Pendekatan Penelitian}

Pendekatan yang digunakan dalam penelitian adalah pendekatan kualitatif deskriptif dengan metode analisis isi karena dimaksudkan untuk mendeskripsikan keadaan sebenarnya dalam penyajian data dan mengkajinya untuk mencari jawaban atas pertanyaan penelitian.Penelitian dengan pendekatan kualitatif deskriptif maka catatan penelitian ditekankan pada pemberian deskripsi kalimat yang rinci, lengkap, mendalam, yang menggambarkan situasi sebenarnya untuk mendukung penyajian data.Data yang telah dikumpulkan dideskripsikan dan dikaji secara mendalam agar diperoleh pemahaman yang lebih nyata terkait tujuan penelitian.

Penelitian ini bertujuan untuk memahami secara mendalam mengenai hal-hal sebagai berikut:
a) Ideologi dalam penerjemahan dari bahasa Inggris ke dalam bahasa Indonesia
b) Teknikyang digunakan oleh penerjemah dalam menerjemahkan buku biografi Suharto : A Political Biography
c) Penyimpangan yang terjadi dalam teks sasaran (Tsa)
d) Faktor-faktor penyebab terjadinya penyimpangan

\section{Tempat dan Waktu Penelitian}

Sumber data yang digunakan dalam penelitian ini berupa buku biografi Suharto :A Political Biografi karya R.E Elson yang telah diterjemahkan ke dalam bahasa Indonesia sehingga tempat penelitian ditentukan oleh penelliti sendiri. Tempat dan waktu penelitian tidak terbatas, yang pasti sejak peneliti mengajukan judul sampai berakhirnya penelitian.

\section{Data dan Sumber Data}

Data yang digunakan untuk analisis ini adalah frasa preposisional lokatif bahasa Inggris yang diterjemahkan ke dalam bahasa 
Indonesia pada biografi Suharto: $A$ Political Biography karangan R.E Elson. Sumber data dalam penelitian ini adalah biografi Suharto: A Political Biography karangan R.E Elson yang diterjemahkan dari bahasa Inggris ke dalam bahasa Indonesia.

\section{E. Prosedur Pengumpulan Data}

Analisis isi (content analysis) sebagai teknik utama pengumpulan data dalam penelitian ini dilakukan melalui beberapa tahapan sebagai berikut:

1. Membaca buku Biografi Politik Suharto : A Political Biography dalam dua versi bahasa secara keseluruhan.

2. Mengidentifikasi dan mengklasifikasi data berdasarkan kategorinya yaitu frasa dalam bahasa Inggris dan frasa dalam bahasa Indonesia.

3. Menyusun urutan data yang telah ditemukan untuk menyelesaikan fokus penelitian berdasarkan prinsip ketersesuaian data.

4. Menyajikan tampilan (display) dan klasifikasi display data dilakukan dengan maksud untuk melihat data secara keseluruhan sedangkan klasifikasi data dipergunakan untuk melihat data sesuai dengan masalah penelitian, proses yang dapat dilakukan adalah melalui pengelompokan data ke dalam bentuk tabel atau bagan.

5. Interpretasi dan verifikasi, setelah langkah-langkah di atas dilakukan, diinterpretasikan sesuai kebutuhan, sehingga proses penelitian terus berkembang secara dinamis. Proses generalisasi senantiasa dilakukan dengan maksud untuk menemukan konsepkonsep dasar yang signifikan dengan masalah penelitian

\section{Hasil Penelitian}

a. Ideologi dan Teknik Penerjemahan

1). Teknik Penerjemahan

\section{Couplet}

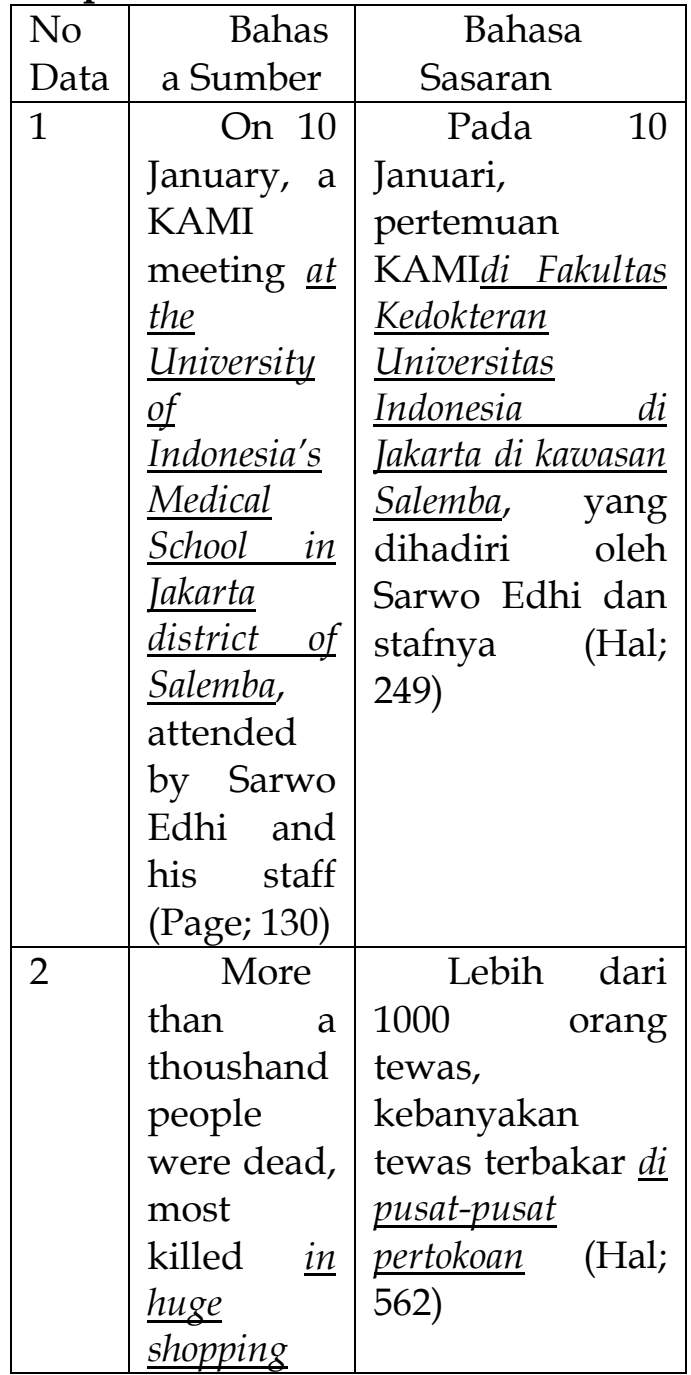




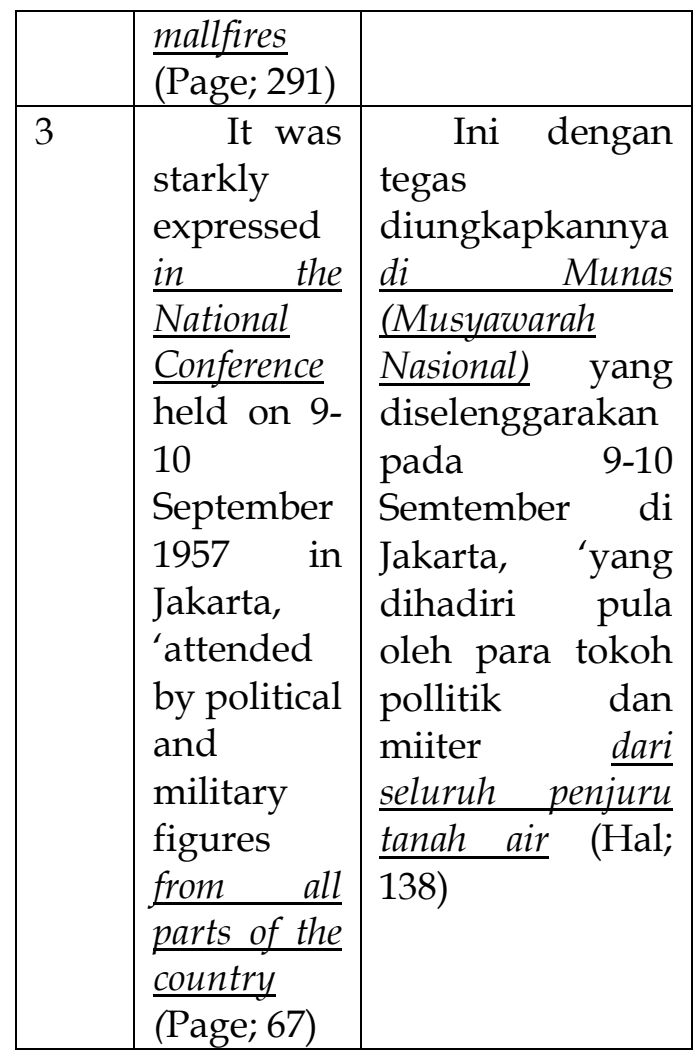

Ideologi penerjemahan berfokus pada gaya pemikiran pada seorang penerjemah dalam menentukan rujukan yang ia gunakan dalam terjemahan yang dibuatnya. Ada dua rujukan ideologi dalam penerjemahan yang dapat dipakai oleh penerjemah yaitu ideologi foreignisasi atau ideologi asing dan ideologi domestikasi atau ideologi lokal. Pada data di atas peneliti berfokus pada tataran penerjemahan frasa. Penerjemah biasanya menentukan ideologi dalam penerjemahan frasa karena juga akan berdampak pada penentuan teknik yang digunakan oleh seorang penerjemah. Pada data pertama ideologi yang digunakan adalah domestikasi. Hal ini terlihat pada diksi Fakultyyang secara natural diserap menjadi fakultas serta medicalyang diterjemahkan menjadi kedokteran untuk disesuaikan dengan budaya masyarakat yang lebih mengenal istilah frasa Fakultas Kedokteran.

Sementara teknik yang digunakan adalah Teknik penerjemahan couplet. Teknik penerjemahan couplet terjadi karena kalimat, klausa atau frasa tidak bisa diterjemahkan hanya dengan satu teknik saja melainkan butuh satu teknik tambahan. Pada data yang pertama terlihat terdapat dua frasa preposisi lokatif at the University of Indonesia's Medical School dan in Jakarta district of Salemba.

Kedua frasa preposisi tersebut bergabung dan memiliki keterkaitan dalam satu kalimat. Penerjemah menerjemahkannya dengan menggunakan teknik Couplet, yang pertama adalah teknik modulasi untuk frasa preposisi lokatif at the University of Indonesia's Medical School. Kata school diterjemahkan menjadi 'fakultas' karena melihat sudut pandang budaya bahasa sasaran yang lebih berterima. Teknik selanjutnya adalah transposisi yang terjadi pada frasa in Jakarta district of Salemba. Pada bahasa sasaran telah terjadi penambahan preposisi ' $i n^{\prime}$ untuk frasa district of Salemba sehingga terjemahannya menjadi di wilayah salemba.

Data yang kedua terdapat dua teknik penerjemahan yaitu teknik transposisi dan teknik pengurangan (reduction). Teknik transposisi terjadi pada kata fires (verba) dalam frasa in 
huge shopping mall fires berpindah posisi di depan frasa preposisi lokatif dalam bahasa sasaran sehingga menjadi 'terbakar (verba) di pusatpusat pertokoaan'. Berikutnya teknik pengurangan dimana pada frasa preposisi lokatif bahasa sumber kata huge yang artinya 'besar' tidak diterjemahkan oleh penerjemah hal ini karena telah ada kata mall yang menunjukan identitas besar. Pengurangan dilakukan penerjemah agar tidak terjadi pemborosan kata pada frasa preposisi tersebut.

Berdasarkan analisa teknik di atas maka dapat disimpulkan ideologi yang digunakan adalah domestikasi. Hal ini disebabkan penerjemah mengusahakan untuk membuat keberterimaan dalam bahasa sasaran. Bila berorientasi pada bahasa sumber maka akan terasa sangat kaku maka perlu penyesuaian dengan berorientasi pada bahasa sasaran sehingga dapat disimpulkan ideologi lokal yang digunakan penerjemah.

Data yang terakhir yang menggunakan teknik kuplet adalah frasa preposisi lokatif from all parts of the country yang diterjemahkan menjadi 'dari seluruh penjuru tanah air'. Teknik yang pertama adalah teknik penerjemahan harfiah, hal tersebut dapat terlihat jelas susunan kata pada frasa preposisi bahasa sumber dan bahasa sasaran yang serupa. Teknik kedua adalah teknik modulasi penerjemah ingin merubah sudut pandang pada kata country sehingga diterjemahkan menjadi 'tanah air' yang lebih akrab dengan budaya bahasa sasaran.
Sementara ideologi yang dipakai oleh penerjemah masih menggunakan ideologi domestikasi. Hal ini terlihat pada kata country yang diterjemahkan dengan menyesuaikan istilah frasa tanah air yang leas terdengar ditelinga masyarakat indonesia dibandingkan bila diterjemahkan menjadi negara.

2). Teknik Penerjemahan Penambahan

\begin{tabular}{|c|c|c|}
\hline $\begin{array}{l}\text { No } \\
\text { Dat } \\
\text { a }\end{array}$ & $\begin{array}{l}\text { Bahasa } \\
\text { Sumber }\end{array}$ & $\begin{array}{l}\text { Bahasa } \\
\text { Sasaran }\end{array}$ \\
\hline 1 & $\begin{array}{l}\text { The } \\
\text { logistics of the } \\
\text { planned } \\
\text { landing, } \\
\text { directed in the } \\
\text { first place at a } \\
\text { series } \\
\frac{\text { uninhabited }}{\text { island south of }} \\
\text { Biak (Page; } 85)\end{array}$ & $\begin{array}{l}\quad \text { Perbekal } \\
\text { an } \\
\text { pendaratan } \\
\text { terencana } \\
\text { itu, awalnya } \\
\text { ditempatkan } \\
\frac{\text { di serangkaian }}{\text { pulau tak }} \\
\frac{\text { berpenduduk }}{\text { di selatan Biak }} \\
\text { (Hal; } 170)\end{array}$ \\
\hline 2 & $\begin{array}{l}\text {....clothing } \\
\text { up forty hours } \\
\text { solo in a Piper } \\
\text { (Page; } 56)\end{array}$ & \begin{tabular}{l}
\multicolumn{1}{c}{$\quad . . . j a m$} \\
terbang \\
solonya \\
sudah \\
mencapai \\
empat puluh \\
jam dalam \\
pesawat Piper \\
(Hal; 116)
\end{tabular} \\
\hline 3 & \begin{tabular}{l}
\multicolumn{1}{c}{ A more } \\
modest \\
commentary \\
from the \\
$\frac{\text { Republic's }}{\text { Sumatra -Based }}$ \\
$\underline{\text { Radio Rimba }}$
\end{tabular} & $\begin{array}{l}\text { Koment } \\
\text { ar yang lebih } \\
\text { rendah hati } \\
\text { dari Radio } \\
\text { Rimbar Raya } \\
\text { milik Republik } \\
\text { di } \quad \text { Sumatra }\end{array}$ \\
\hline
\end{tabular}




\begin{tabular}{|l|l|l|}
\hline 4 & $\begin{array}{l}\text { Raya (Page; 35) } \\
\text { Pressure } \\
\text { on the Dutch to } \\
\text { cease } \\
\text { operations and } \\
\text { reembark upon } \\
\text { negotiations } \\
\text { withtheRepubl } \\
\text { ic }\end{array}$ & $\begin{array}{l}\text { Dewan } \\
\text { keamanan } \\
\text { menekan } \\
\text { Belanda agar } \\
\text { menghentika } \\
\text { n operasi } \\
\text { dan kembali } \\
\text { memulai } \\
\text { perundingan } \\
\text { denganRI }\end{array}$ \\
\hline 5 & $\begin{array}{l}\text { Suharto's } \\
\text { final task in the } \\
\text { revolution was } \\
\text { to escort the } \\
\text { Army } \\
\text { commander, } \\
\text { Sudirman, } \\
\text { back } \\
\text { Yogyakarta. }\end{array}$ & $\begin{array}{l}\text { Tugas } \\
\text { terakhir } \\
\text { Suharto } \\
\text { dalam } \\
\text { perjuangan } \\
\text { adalah } \\
\text { mengawal } \\
\text { panglima } \\
\text { TNI, } \\
\text { Sudirman, } \\
\text { kembali ke } \\
\text { Yogyakarta. }\end{array}$ \\
\hline
\end{tabular}

Data teknik penambahan (addition) pada data nomor 4 yang menggunakan preposisi at terdapat frasa preposisi lokatif at a series of uninhabited island south of Biak yang diterjemahkan menjadi 'di serangkaian pulau tak berpenduduk di selatan Biak'. Bila kita perhatikan dengan seksama tidak ada yang salah pada penerjemahan frasa preposisi lokatif tersebut, akan tetapi penerjemah telah menambah satu preposisi pada bahasa sasaran yaitu pada frasa south of Biak yang diterjemahkan menjadi 'di selatan Biak'. Ideologi yang digunakan adalah ideologi domestikasi dimana penerjemahan menerangkan dengan lebih jelas bahwa frasa serangkaian pulau terletak di selatan Biak. Teknik penambahan memang sangat jelas berorientasi pada bahasa sasaran karena penerjemah memberi keterangan penjelas pada sturuktur kalimat sehingga pembaca memahami apa yang dimaksud dari isi teks.

Pada data nomor 6 frasa preposisi lokatif in a Piper diterjemahkan dengan menggunakan teknik penambahan (addition). Bila diterjemahkan dengan teknik harfiah menjadi 'dalam sebuah piper' meski 'piper' adalah nama pesawat namun tidak semua orang mengetahui bahwa itu adalah nama pesawat, sehingga penerjemah menambah kata pesawat (nomina) dalam bahasa sasaran. Pada data yang ke -6 memiliki kesamaan dengan jenis penambahan pada data sebelumnya. Penerjemah telah menambah satu preposisi pada bahasa sasaran yaitu Republic's Sumatra yang diterjemahkan menjadi 'Republik $\underline{\text { di }}$ Sumatra'.

Pada data di atas memiliki kesamaan pada data sebelumnya dimana penerjemah melakukan penambahan kata penjelas yaitu pesawat. Hal tersebut disebabkan untuk menghindari kerancuan terjemahan maka perlu dilakukan penambahan kata agar pembaca mengerti bahwa yang dimaksud adalah sebuah pesawat. Pada data selanjutnya juga memiliki kesamaan dengan penambahan partikel imbuhan di- yang fungsinya jelas utuk menekankan pada informasi yang dimaksud. Dari penjelasan di atas maka dapat ditarik kesimpulan bahwa ideologi yang digunakan adalah ideologi domestikasi atau lokal. 
Pada data 4, penerjemah menggunakan ideologi domestikasi. Ideologi domestikasi sesuai dengan keterangan Hoed (2006) dipilih oleh penerjemah dengan kepercayaan bahwa terjemahan yang 'betul', 'berterima', dan 'baik' adalah yang memenuhi harapan pembaca sasaran yang menginginkan teks terjemahan harus sesuai dengan kebudayaan masyarakat sasaran pada BSa. Kata 'the republic' diterjemahkan menjadi 'RI' atau 'Republik Indonesia'. Hal ini dilakukan oleh penerjemah karna apabila kata 'the republic' hanya diterjemahkan sebagai 'republik', maka penerjemah tidak bisa menyampaikan pesan pada BSu ke BSa dengan akurat, oleh karna itu penerjemah menggunakan ideologi domestikasi dengan menerjemahkan kata 'the republic' menjadi 'republik Indonesia'.

Teknik yang digunakan pada data 4 adalah teknik addition atau penambahan. Kata 'the republic' pada BSu diterjemahkan menjadi 'Republik Indonesia pada BSa. Hal ini menunjukkan adanya penambahan kata 'Indonesia', yang mana kata tersebut tidak ada dalam BSu, tetapi ditambahkan oleh penulis dalam BSa.

Pada data 5, ideologi domestikasi dipilih oleh penulis adalah ideologi domestikasi, yang mana lebih mementingkan keterbacaan dan kesesuaian dengan kultur budaya masyarakat sasaran. Frasa 'theArmy commander' pada $\mathrm{BSu}$ diterjemahkan menjadi frasa'panglima TNI'. hal ini bisa dianalisis bagaimana istilah 'army' diterjemahkan menjadi TNI atau
'Tentara Nasional Indonesia'. Ideologi domestikasi disini dapat dilihat dari kata 'army' yang diterjemahkan menjadi 'TNI'.

Teknik terjemahan yang digunakan pada data 5 adalah teknik addition, dimana informasi yang tidak dijekaskan pada BSu ditambahkan di BSa. Kata 'army' diterjemahkan ke dalam BSa dengan penambahan informasi menjadi 'TNI' yang merupakan singkatan dari Tentara Nasional Indonesia. Disini menunjukkan adanya addition atau penambahan dari BSu ke BSa.

\begin{tabular}{|c|c|c|}
\hline \multicolumn{3}{|c|}{ Harfiah } \\
\hline $\begin{array}{l}\text { No } \\
\text { Data }\end{array}$ & $\begin{array}{l}\text { Bahasa } \\
\text { Sumber }\end{array}$ & $\begin{array}{l}\text { Bahasa } \\
\text { Sasaran }\end{array}$ \\
\hline 1 & $\begin{array}{l}\text { Suharto } \\
\text { himself } \\
\text { became the } \\
\text { first } \\
\text { individual } \\
\text { member of } \\
\text { Golkar at a } \\
\text { ceremony at } \\
\text { his home in } \\
\text { January } \\
\text { 1984 (Page; } \\
\text { 245) }\end{array}$ & $\begin{array}{l}\text { Suharto } \\
\text { sendiri menjadi } \\
\text { anggota } \\
\text { perorangan } \\
\text { Golkar yang } \\
\text { pertama dalam } \\
\text { sebuah upacara } \\
\text { di rumahnya } \\
\text { pada Januari } \\
1984 \text { (Hal; } 471)\end{array}$ \\
\hline 2 & $\begin{array}{l}\text { Suharto } \\
\text { 's brigade, } \\
\text { like others } \\
\text { in the new } \\
\text { Division, } \\
\text { comparised } \\
\text { four } \\
\text { battalions, } \\
\text { themselves } \\
\text { requiring } \\
\text { foarmation. } \\
\text { (Page; 24) }\end{array}$ & \begin{tabular}{l}
\multicolumn{2}{c}{ Brigade } \\
Suharto, seperti \\
Brigade yang \\
lain $\frac{\text { dalam }}{\text { baru, }}$ \\
Divisi dari \\
terdiri drallion \\
empat batall \\
yang masing- \\
masing juga \\
memerlukan \\
perombakan \\
(Hal; 64)
\end{tabular} \\
\hline
\end{tabular}




\begin{tabular}{|c|c|c|}
\hline 3 & \begin{tabular}{l}
\multicolumn{1}{c}{ With } \\
his move to \\
Bandung, \\
Suharto \\
moved \\
forever from \\
the small- \\
town world of \\
Central Java \\
(Page; 75$)$
\end{tabular} & $\begin{array}{l}\text { Dengan } \\
\text { kepindahannya } \\
\text { ke Bandung, } \\
\text { Suharto pindah } \\
\text { untuk } \\
\text { selamanya dari } \\
\text { dunia kota kecil } \\
\text { Iawa Tengah } \\
\text { (Hal; 153) }\end{array}$ \\
\hline 4 & $\begin{array}{l}\text { As the } \\
\text { first step in } \\
\text { a process of } \\
\text { establishing } \\
\text { an interim } \\
\text { federal } \\
\text { government } \\
\text { of Indonesia }\end{array}$ & \begin{tabular}{l}
\multicolumn{1}{c}{ Sebagai } \\
langkah \\
pertama dalam \\
proses \\
pembentukan \\
pemerintah \\
federalad \\
interim \\
Indonesia
\end{tabular} \\
\hline
\end{tabular}

Teknik penerjemahan harfiah merupakan teknik yang paling banyak muncul pada setiap proses penerjemahan. Data nomor 7 frasa preposisi at a ceremony at his home yang diterjemahkan menjadi 'dalam sebuah upacara di rumahnya'. Terlihat struktur yang sama dari kedua bahasa, meskipun memiliki kemiripan dengan penerjemahan kata demi kata namun penerjemahan harfiah tetap mengedepankan pesan yang berterima pada bahasa sasaran. Hal ini terlihat pada penerjemahan frasa his home yang diterjemahkan menjadi 'rumahnya' bukan 'nya rumah.

Teknik penerjemahan harfiah sangat mengedepankan maksud dan keinginan dari bentuk dan makna bahasa sumber sehingga teknik penerjemahan harfiah lebih kental dengan penerjemahan kata per kata. Penerjemahan kata demi kata berorientasi pada bahasa sumber sehingga nampaklah ideologi foreignisasi atau ideologi asing diterapkan oleh seorang penerjemah.

Berikutnya frasa preposisi lokatif yang dibentuk dari preposisi in yaitu in the new Division yang diterjemahkan dengan teknik harfiah menjadi 'dalam Divisi baru'. Pada bahasa sumber terlihat struktur in (preposisi), the new Division (frasa nomina) dan pada bahasa sasaran yang serupa yaitu 'dalam' (preposisi), 'Divisi baru' (frasa nomina). Data di samping menggambarkan bahwa penerjemah menggunakan ideologi foreignisasi karena penerjemah mempertahankan bentuk pada bahasa sumber yang kemudian disesuaikan dengan bentuk yang berterima pada bahasa sasaran.

Data yang terakhir adalah frasa preposisi lokatif yang dibentuk dari preposisi from yaitu from the smalltown world of Central Java. Frasa tersebut diterjemahkan menggunakan teknik harfiah menjadi 'dari dunia kota kecil Jawa Tengah'. Bila kita analisis struktur utamanya terlihat pada bahasa sumber dan bahasa sasaran yaitu mulai dari preposisi from yang diterjemahkan 'dari', frasa nomina the smal town world tidak diterjemahkan dengan kata demi kata tapi lebih dekat dengan bahasa sumber menjadi 'dunia kota kecil'. Hal itu membuktikan bahwa penerjemah menggunakan teknik harfiah dalam menerjemahkan frasa preposisi lokatif tersebut.

Terlihat dari peneyempurnaan teknik di atas bahwasanya penerjemah telah menggunakan 
ideologi foreignisasi. Orientasi yang digunakan oleh penerjemah adalah orientasi pada bahasa sumber sehingga pengaruh ideologi foreignisasi sangat terasa pada penerjemahan frasa tersebut di atas. Sehingga dapat disimpulkan bahwa ideologi asing (foreignisasi) yang penerjemah gunakan.

Pada data 4, frasa 'federal government' diterjemahkan menggunakan ideologi foreignisasi. Ideologi foreignisasi pada data diatas dilakukan penerjemah agar pembaca sasaran dapat mengetahui secara langsung istilah yang ada pada masa sejarah perjuangan Indonesia dibawah agresi Belanda. Istilah 'federal government' diterjemahkan menjadi 'pemerintah federal'. Dengan menggunakan ideologi foreignisasi, penulis dapat menyampaikan informasi kepada pembaca untuk memberikan wawasan baru kepada mereka.

Teknik yang digunakan pada data 4 adalah teknik penerjemahan harfiah. Hal ini terlihat dari frasa 'federal government' yang diterjemahkan menjadi 'pemerintah federal'. Ini sesuai dengan definisi teknik harfiahyaitu penerjemahan yang dilakukan dengan cara menerjemahkan kata perkata dengan menyesuaikan struktur BSa, dalam hal ini bahasa Indonesia.

\section{4). Teknik Penerjemahan}

Pengurangan

\begin{tabular}{|c|c|c|}
\hline $\begin{array}{l}\text { No } \\
\text { Data }\end{array}$ & $\begin{array}{l}\text { Bahasa } \\
\text { Sumber }\end{array}$ & $\begin{array}{l}\text { Bahasa } \\
\text { Sasaran }\end{array}$ \\
\hline 1 & $\begin{array}{r}\text { Calling } \\
\text { press }\end{array}$ & $\begin{array}{ll} & \text { Mengadak } \\
\text { an } & \text { konferensi }\end{array}$ \\
\hline
\end{tabular}

\begin{tabular}{|c|c|c|}
\hline & \begin{tabular}{l}
\multicolumn{3}{l}{ conference $\underline{a t}$} \\
his $\quad$ Bina \\
Graha office \\
rather than \\
his home \\
$($ Page; 3)
\end{tabular} & $\begin{array}{l}\text { pers di kantor } \\
\text { Bina } \frac{\text { Graha }}{\text { alih-alih }} \\
\text { dirumahnya } \\
\text { (Hal; 29) }\end{array}$ \\
\hline 2 & 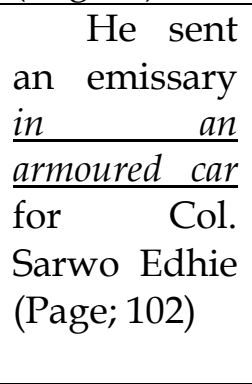 & 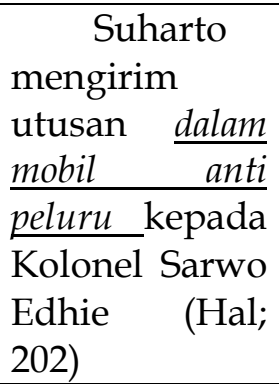 \\
\hline 3 & $\begin{array}{l}\quad \text { At the } \\
\text { same time, } \\
\text { the arrival of } \\
\text { troops from } \\
\text { West Java's } \\
\frac{\text { Siliwangi }}{\text { Division into }} \\
\text { Central Java } \\
\text { (Page; } 24)\end{array}$ & \begin{tabular}{lr}
\multicolumn{1}{r}{ Pada } & $\begin{array}{r}\text { saat } \\
\text { yang }\end{array}$ \\
pama, \\
pasukan & Divisi \\
Siliwangi & Jawa \\
$\underline{\text { Barat }}$ & datang \\
ke & Jawa \\
Tengah & (Hal; \\
$63)$ &
\end{tabular} \\
\hline
\end{tabular}

Teknik

pengurangan (reduction) kerap dilakukan oleh penerjemah untuk menghindari kerancuan dan pemborosan kata dalam proses penerjemahan. Contoh yang pertama untuk penggunaan teknik pengurangan (reduction) pada frasa preposisi lokatif at his Bina Graha office yang diterjemahkan menjadi 'di kantor Bina Graha'. Dapat kita perhatikan dengan seksama penerjemah tidak menerjemahkan kata his hal ini menyebabkan terjadinya pengurangan informasi gender. Hal ini juga disebabkan karena dalam bahasa sasaran yaitu bahasa Indonesia tidak memiliki aturan yang ketat tentang bentuk 
kepemilikan (possessive) seperti halnya bahasa Inggris.

Ideologi penerjemahan yang dipilih oleh penerjemah adalah ideologi domestikasi dimana penyesuaian banyak dilakukan pada bahasa sasaran. Hal tersebut dilakukan bertujuan untuk mencapai keberterimaan dalam bahasa sasaran dan agar tidak terjadi kerancuan dalam penggunaan bahasa dan ungkapan tertentu sehingga pemilihan ideologi lokal atau domestikasi dirasa sudah sangat tepat.

Contoh yang kedua pada ke-11 yaitu frasa preposisi lokatif in an armoured car yang diterjemahkan menjadi 'dalam mobil anti peluru'. Penggunaan kata sandang (article) dalam bahasa Inggris sangatlah penting untuk menunjukan kedudukan suatu benda. Namun dalam bahasa Indonesia kata sandang tidaklah terlalu dianggap penting sehingga penerjemah mengurangi kata sandang an dalam penerjemahan frasa preposisi lokatif tersebut. Ideologi yang digunakan pada data di atas adalah ideologi domestikasi dimana penyesuaian dilakukan demi keberterimaan dalam bahasa sasaran.

Contoh yang terakhir pada tabel diatas adalah frasafrom West Java's Siliwangi Division yang diterjemahkan dengan menggunakan teknik pengurangan (reduction) menjadi 'Divisi Siliwangi Jawa Barat'. Penerjemah ingin membuat kalimat yang lebih efektif sehingga penerjemah mengurangi preposisi from pada penerjemahan frasa preposisi lokatif tersebut. Ideologi yang tepat digunakan oleh penerjemah adalah ideologi domestikasi walaupun dengan pengurangan tersebut tidak berpengaruh pada makna yang tetap sama dengan bahasa sumber.

\section{Kesimpulan}

Fokus penelitian ini melihat bagaimana penggunaan ideologi serta penerapan teknik, penyimpangan dan faktor penyebab penyimpangan dalam menerjemahkan buku biografi Suharto: A Political Biography karya R.E Elson. Data yang ditemukan disajikan berdasarkan keterkaitannya dengan Ideologi Penerjemahan. Total data yang ditemukan berjumlah 62 data yang ditemukan oleh peneliti kemudian dianalisis berdasarkan teori yang digunakan. Berikut sebaran data yang ditemukan;

\section{A. Ideologi Penerjemahan}

\begin{tabular}{|c|c|c|c|}
\hline $\mathrm{NO}$ & $\begin{array}{l}\text { Teknik } \\
\text { Penerjema } \\
\text { han }\end{array}$ & $\begin{array}{l}\text { Ideologi } \\
\text { Foregni } \\
\text { sasi }\end{array}$ & $\begin{array}{l}\text { Ideologi } \\
\text { Domesti } \\
\text { kasi }\end{array}$ \\
\hline 1 & Couplet & 3 & \\
\hline 2 & $\begin{array}{l}\text { Addition } \\
\text { / Penamba } \\
\text { han }\end{array}$ & 5 & \\
\hline 3 & Harfiah & & 4 \\
\hline 4 & $\begin{array}{l}\text { Reductio } \\
\mathrm{n} / \text { Pengur } \\
\text { angan }\end{array}$ & 3 & \\
\hline 5 & $\begin{array}{l}\text { Transposis } \\
\text { i }\end{array}$ & 8 & 1 \\
\hline 6 & Modulasi & 3 & \\
\hline 7 & $\begin{array}{l}\text { Natural } \\
\text { Borrowing }\end{array}$ & & 7 \\
\hline 8 & $\begin{array}{l}\text { Pure } \\
\text { Borrowing }\end{array}$ & & 12 \\
\hline
\end{tabular}




\begin{tabular}{|l|l|l|l|}
\hline 9 & Adaptasi & 3 & \\
\hline 10 & Substitusi & 1 & \\
\hline 11 & Shift & 14 & \\
\hline \multicolumn{2}{|c|}{$40+24=64$} \\
\hline
\end{tabular}

Kecenderungan penggunaan ideologi Domestikasi lebih kuat yaitu sebanyak 40 data sementara ideologi forereignisasi sebanyak 24 data. Pada saat seorang penerjemah berhadapan dengan bentuk atau istilah atau apapun dari teks bahasa sumber yang memerlukan pertimbangan khusus apakah ia harus mempertahankan bentuk seperti yang terdapat dalam bahasa sumber karena pertimbanganpertimbangan tertentu ataukah harus merubah untuk memudahkan pembaca memahami.dengan cara membuat sesuatu yang lebih dekat dengan khalayak pembaca, dia sedang berada pada posisi harus memutuskan apakah domestikasi atau foreignisasi.

Ideology Asing (Foreignization) dan Ideology Lokal (domestication) adalah dua ideologi yang bekerja pada dua tingkat, yaitu tingkat makro dan mikro. Yang pertama menentukan teks apa yang perlu diterjemahkan dan yang lainnya menentukan strategi, metode atau teknik yang diterapkan dalam proses terjemahan. Ideologi yang disukai oleh penerjemah dapat diidentifikasi melalui strategi yang diterapkannya. Dengan kata lain, penulis dapat mengungkapkan ideologi yang disukai oleh penerjemah melalui strategi penerjemahan. Artinya, peneliti perlu mencari tingkat paling bawah (strategi terjemahan) terlebih dahulu dan kemudian beralih ke tingkat yang lebih tinggi, yaitu ideologi terjemahan.

\begin{tabular}{|l|l|c|l|}
\hline NO & Teknik & Jml & $\%$ \\
\hline 1 & Couplet & 3 & $4,68 \%$ \\
\hline 2 & $\begin{array}{l}\text { Addition/P } \\
\text { enambahan }\end{array}$ & 5 & $7,8 \%$ \\
\hline 3 & Harfiah & 4 & $6,25 \%$ \\
\hline 4 & $\begin{array}{l}\text { Reduction/ } \\
\text { Penguranga } \\
\text { n }\end{array}$ & 3 & $4,68 \%$ \\
\hline 5 & Transposisi & 9 & $14 \%$ \\
\hline 6 & Modulasi & 3 & 4,6 \\
\hline 7 & $\begin{array}{l}\text { Natural } \\
\text { Borrowing }\end{array}$ & 7 & 11 \\
\hline 8 & $\begin{array}{l}\text { Pure } \\
\text { Borrowing }\end{array}$ & 12 & $16,75 \%$ \\
\hline 9 & Adaptasi & 3 & $4,68 \%$ \\
\hline 10 & Substitusi & 1 & $1,56 \%$ \\
\hline 11 & Shift & 14 & $22 \%$ \\
\hline \multicolumn{2}{|l|}{ Jumlah } & 64 & $100 \%$ \\
\hline
\end{tabular}

Dari data di atas terlihat bahwa dominasi penggunaan teknik shiftsebanyak 14 data (22\%) dan teknik pure borrowing 12 data (16,75\%). Kedua teknik tersebut berorientasi pada ideologi foreignisasi dan domestikasi.

\section{Referensi}

${ }^{1}$ Midred L. Larson, Meaning-Based Translation: A Guide to Cross Language Equivalence(Boston: University Press of America, 1984), h. 3. 
${ }^{2}$ Basil Hatim dan Jeremy Munday, Translation an advance resource book (New York: Routledge, 2004), h.143.

3Mazi-Leskovar, Darja."Domestication andForeignization in TranslatingAmerican Prose for SlovenianChildren".dalamMeta.XLVIII, 1-2, Hal 250-265.

${ }^{4}$ Venuti, Lawrence.TheTranslator's Invisibility: AHistory of Translation. (London: Routledge, 1995). h. 21

${ }^{5}$ Hoed,Benny.Penerjemahan dan Kebudayaan. (Jakarta: Pustaka Jaya, 2006) h. 67

${ }^{6}$ Ibid, h. 83

7Ibid, h. 84

8Ibid, h. 83-90

9Ibid, h. 84

${ }^{10}$ Gorys Keraf, Tata Bahasa Rujukan Bahasa Indonesia (Jakarta: PT Grasindo, 1991), h. 175.

${ }^{11}$ Ibid.

${ }^{12}$ Harimurti Kridalaksana, Beberapa Prinsip Perpaduan Leksem Dalam Bahasa Indonesia (Yogyakarta: Kanisius, 1988), h. 81.

${ }^{13}$ Lamuddin Finoza, Komposisi Bahasa Indonesia(Jakarta: Diksi, 2008), h. 101.

${ }^{14}$ Scott Thornbury, An A-Z ELT (UK:

Mac Millan Book, 2002), h. 167.

${ }^{15}$ Harimurti Kridalaksana, op.cit., hh. 81-85.

${ }^{16}$ Widjono Hs, Bahasa Indonesia (Jakarta: Grasindo, 2012), h. 178.

17 Scott Thornbury, op. cit.,hh. 167168

18 Molina dan Alber, 2002.

"Translation Techniques Revisited:A Dynamic and Functionalist Approach" dalam Meta: Journal des Traducteurs/Meta: Translators' Journal. XLVII, No. 4 hal. 498-512. diunduh dari http://id.erudit.org/iderudit/008033ar.p df pada tanggal 22 Desember 2013

19 Emzir, Metode Penelitian KualitatifAnalisis Data (Jakarta: Rajawali Press, 2010), h. 283.
${ }^{20}$ Robert Philip Weber, Basic Content Analysis (London: Sage Publication, 1990), h. 9.

${ }^{21}$ Klaus Krippendorf, Content Analysis: An Introduction to its Methodology (London: Sage, 2004), h. xiii.

${ }^{22}$ Lisa M Given, The Sage Encyclopedia of Qualitative Research (London: Sage Publication, 2008), h. 120.

${ }^{23}$ Donald Ary, Introduction to Research

Education (USA: Wadsworth, 2010), h. 457

\section{Buku}

Ary, Donald.Introduction to Research Education.USA: Wadsworth, 2010.

Baker, Mona. In Other Words : A

Coursebook on Transation. New

York: Routledge, 2011.

Bassnett, Susan. Translation Studies. New York: Routledge, 2002.

Bell, Roger. Translation and Translating : Theory and Practice. New York: Longman Inc, 1991.

Catford,J.C. A Linguistics Theory of Translation: An Essay in Applied Linguistics. Newyork: Oxford University Press, 1975.

Elson, R.E. Suharto A Political Biography. London: Cambridge University Press, 2001.

Emzir.Metodologi Penelitian Kualitatif Analisis Data. Jakarta: Rajawali Press, 2010.

Given, Lisa M. The Sage Encyclopedia of Qualitative Research. London: Sage Publication, 2008.

Hatim, Basil dan Munday.Translation an advance resource book. New York: Routledge, 2004.

Hoed, Benny.Penerjemahan dan Kebudayaan.Jakarta: Pustaka Jaya, 2006 
Kardimin, Pintar Menerjemah. Yogyakarta: Pustaka Pelajar, 2012.

Krippendorf,Klaus. Content Analysis:

An Introduction to its Methodology. London: Sage, 2004.

Kussmull, Paul. Training The

Translation. Amsterdam: JB

Publishing Company,.1995

Larson, Midred L. Meaning-Based Translation: A Guide to Cross Language Equivalence. Boston: University Press of America, 1984.

Machali, Rochaya. Pedoman bagi penerjemah.Jakarta: Gramedia Widiasarana, 2000.

Mazi-Leskovar,

Darja."Domestication and Foreignization

in TranslatingAmerican Prose for

SlovenianChildren".dalam Meta.XLVIII, 1-2, Hal 250-265.

Moentaha.Bahasa dan Terjemahan. Jakarta: Kesaint Blanc, 2008.

Moeliono,Anton. Tata Bahasa Baku Bahasa Indonesia. Jakarta: Balai Pustaka, 2003.

Molina dan Alber, 2002. "Translation Techniques Revisited: A Dynamic and Functionalist Approach" dalam Meta: Journal des Traducteurs/Meta: Translators' Journal. XLVII, No. 4 hal. 498-512. diunduh dari http://id.erudit.org/iderudit/008 033ar.pdf pada tanggal 22 Desember 2013

Mona Baker, In Other Words : A Coursebook on Transation. New York: Routledge, 2011

Munday,Jeremy. Introducing Translation Studies: Theories and Application. London: Routledge, 2001.
Nababan.Teori Menerjemah Bahasa Inggris. Yogyakarta: Pustaka Pelajar, 2003.

Newmark.A Textbook of Translation. Newyork/London : Prantice Hall, 1988.

Nida dan Taber.The Theory and Practice of Translation.Leiden : E.J Brill, 1974.

Nida, Eugene. Towars a science of Translating.Leiden : E.J Brill 1964.

Nord, Cristiane. Translation Theories Explained. Manchester: ST Jerome. 2007.

Philip Weber, Robert. Basic Content Analysis. London: Sage Publication, 1990.

Venuti, Lawrence.The Translator's Invisibility: A History of Translation.London: Routledge, 1995

Wilss, Wolfram. Knowledge and Skills in Translation Behavior. Amstrerdam: JB Publishing Company,1996. 